\title{
Chemical composition, free radical scavenging and antifungal activity ofZanthoxylumleprieuriiessential oils against Epidermophytonfloccosum and Trichophytonrubrum
}

\author{
Tchabong $^{1}$,S.R., Jazet ${ }^{1}$, D.P.M., Sameza ${ }^{1 *}$, M.L., Tchameni ${ }^{1}$, N.S. \\ Mounbain ${ }^{1}$ F.,Mouelle ${ }^{2}$,S.A., Menut ${ }^{3}$, C. andTchoumbougnang ${ }^{1}$, F. \\ ${ }^{1}$ Laboratory of Biochemistry, Faculty of Science, University of Douala, P.O. Box 24157 Douala Cameroon \\ ${ }^{2}$ Faculty of Medicine and Pharmaceutical Science, University of Douala, P.O. Box 571 Douala, Cameroon \\ ${ }^{3}$ Equipe "Glyco et nano vecteurs pour le ciblage thérapeutique", IBMM, Faculté de Pharmacie, 15 Avenue Charles \\ Flahault, BP 14491, 34093 Montpellier, France
}

\begin{abstract}
Background: These investigations were carried out to analyze the chemical composition, to evaluate the radical scavenging, and the anti-fungal activities of essential oils from leaves and fruits of Zanthoxylumleprieurii.

Methods: Oils were obtained by hydro distillation using Clevenger-type apparatus. The compounds were identified by gas chromatography and gas chromatography coupled with Mass Spectrometry. Antifungal activity of the essential oils was tested in vitro agains Epidermophytonfloccosum and Trichophytonrubrumwhile free radical scavenging activity evaluation was done using 2,2-diphenyl picrylhydrazyl method.
\end{abstract}

Results: Results showed that, the major components of the leaves oil were (E)- $\beta$-ocimene $(91.5 \%)$ while the most abundant component from fruits oil were (E)-ß3-Ocimene $(90.3 \%)$. The total growth inhibition of the pathogens by fruits essential oil occurred at $4.0 \mathrm{mg} / \mathrm{ml}$ and $3.0 \mathrm{mg} / \mathrm{ml}$ respectively, forEpidermophytonfloccosum and Trichophytonrubrum. The leaves oil exhibited total growth inhibition at 4.0 $\mathrm{mg} / \mathrm{ml}$ against both pathogens. These oils also showed antioxidant activities with $\mathrm{SC}_{50}$ values at $2.0 \mathrm{mg} / \mathrm{ml}$ and $5.0 \mathrm{mg} / \mathrm{ml}$ respectively, for fruits and leaves. There were positive and significant correlations between mycelia growth inhibition of both pathogens and the antioxidant activities of the tested oils noted.

Conclusion: These results showed that, Z. leprieurii essential oils could be used as a resource of antioxidant and antidermatophitic compounds with may find applications in pharmaceutical industries.

Key words:Essential oil, Antidermatophytitic activity, Antioxidant activity,Zanthoxylumleprieurii

\section{INTRODUCTION}

Cutaneous mycosis is a human dermatophytosis which is the most common infection in skin and nail worldwide especially in Sub-Africa countries including Cameroon. This infection is often caused by filamentous fungi belonging to the genera Epidermophyton, Trichophyton and Microsporum[1].Among them, E. floccosum and T. rubrumare widespread in most countries of the world, accounting for $5 \%$ of all dermatophytes isolated [2]. Some preliminary works in Cameroon found that these two fungi were the most prevalent cutaneous mycosis. These fungiare anthropophilic dermatophytes that are transmitted between individuals by contact, particularly in community swimming pool areas, common showers, and gym facilities. The clinical presentation predisposing factors for mycosis include immunosuppression, diabetes mellitus, advanced age nail trauma, and poor peripheral circulation [3]. Free radicals are produced in normal and or pathological cell metabolism. Oxidation is essential to many living organisms for the production of energy to fuel biological processes. However, the uncontrolled production of oxygen derived free radicals is involved in triggering many diseases including dermatosis. Exogenous chemical and endogenous metabolic processes in the human body might produce highly reactive free radicals, especially oxygen derived radicals, which are capable of oxidizing biomolecules, resulting in cell death and tissue damage [4].The clinical care of cutaneous mycosis is based on combination of a topical and systemic chemical antifungals treatment. However, synthetic antifungals suffer from various weaknesses in terms of toxicity, lack of fungicidal efficacy, cost and emergence of resistant strains caused by the frequent use of some of them [5]. In spite of the recent introduction of new antifungal drugs, they are still limited in number. Hence, there is a great demand for novel antifungal agents, justifying the intense search for new drugs that are more effective and less toxic than those already in use [6,7]. An alternative should be used for plant derivate products such as the essential oils (EO) to control dermatophytes infections.

Essential oils are the odorous, volatile products of plant secondary metabolism normally formed in special cells or groups of cells or as glandular hair, found on any organ of the plant including roots, stem, leaves, flowers and fruits. EO have demonstrated various biological activities including anticancer, antiviral, antibacterial, antifungal and antioxidant activities $[8,9,10]$; as well as their ability to facilitate the passage of active molecules through the human tissues [11].Zanthoxylumleprieurii is a large species of the family of Rutaceae which is geographically distributed across Africa. In traditional Cameroon medicine, this plant is used for the treatment of intestinal worms, abdominal pain, hyperhermia, diarrhea and certain mycosis [12]. Previous works have demonstrated the antimicrobial activities of Zanthoxylumleprieurii essential oil from Cameroon [13]. However, in the best our knowledge there is no report on the antifungal properties of this oil against $E$. floccosumand $T$. rubrum. The aim of this study was to analyze the chemical composition of Zanthoxylumleprieuriiessential oils and to evaluate their antioxidant and antifungal activities against E. floccosumand T. rubrum, the two most common causal agents of cutaneous mycosis. 
Leaves and fruits of $Z$. leprieuriiwere collected at Bamena (West Region of Cameroon) on July 2014. The herbarium/plants were identified at the National Herbarium where voucher specimen was deposited under the reference 2713/SRFK/CAM.

\section{Essential oils extraction}

About 200-400 g of air-dried leaves and fruits (after grounded) were coarsely crushed. Each sample was distillated for about $4 \mathrm{~h}$ using Clevenger-type apparatus. Essential oils collected were dried over anhydrous sodium sulphate, stored in an ambercolored flask and kept at $4^{\circ} \mathrm{C}$ until use.

\section{Essential oils analysis}

Essential oils were analysed by gas chromatography (GC) and gas chromatography coupled with mass spectrometry (GC/MS).

\section{Gas chromatography}

Each oil was analysed on a Varian CP-3380 GC with flame ionisation detector fitted with a fused silica capillary column (30 $\mathrm{m} \times 0.25 \mathrm{~mm}$ coated with DB-5, film thickness $0.25 \mu \mathrm{m}$ ); temperature program $50^{\circ} \mathrm{C}-200^{\circ} \mathrm{C}$ at $5^{\circ} \mathrm{C} / \mathrm{min}$, injector temperature $200^{\circ} \mathrm{C}$, detector temperature $200^{\circ} \mathrm{C}$, carrier gas $\mathrm{N}_{2} 1 \mathrm{ml} / \mathrm{min}$. The linear retention indices of the components were determined relatively to the retention times of a series of $n$-alkanes and the percentage compositions were obtained from electronic integration measurements without taking into account relative response factors.

\section{Gas chromatography coupled with mass spectrometry}

GC-MS analyses were carried out using a furnace Focus GC (Thermo) apparatus equipped with a TG-5MS5MS column (30 $\mathrm{m} \times 0.25 \mathrm{~mm}$, film thickness, $0.25 \mu \mathrm{m}$ ) and interfaced with a quadruple detector (DSQ II). Column temperature was programmed from 60 to $200^{\circ} \mathrm{C}$ at $10^{\circ} \mathrm{C} / \mathrm{mn}$; injector temperature was $220^{\circ} \mathrm{C}$. The injections were carried out in mode SPLIT (Ratio: 1/100). Helium was used as carrier gas at a flow rate of $1.2 \mathrm{ml} / \mathrm{min}$; the mass spectrometer was operated at 70 $\mathrm{eV}$. The components were identified based on the comparison of their retention indices and their mass spectra with those given in the literature [14].

\section{Fungalpathogen}

Epidermophytonfloccosum andTrichophytonrubrum used in this study were isolated from male patient at the General Hospital of Douala (Cameroon). Skin and nail scales of fungal lesion from patient were cultured on Sabouraud Dextrose Agar supplemented with chloramphenicol. After 21 days of incubation at $28{ }^{\circ} \mathrm{C}$, the mycelia emerging from tissues were transferred into fresh Sabouraud medium. The operation was repeated many times to obtain pure culture of each isolate. Identification of both fungi isolate was based on macroscopic and microscopic criteria according to the method described by $[15,16]$.Thecultures were stored at $4^{\circ} \mathrm{C}$ and sub-culture every three month.

\section{Antifungal assay}

The inhibition of mycelia growth was performed using agar incorporation method [17].

The test was carried out in $90 \mathrm{~mm}$ Petri dishes containing SDA medium supplemented with chloramphenicol. Four millimeters diameter disc was taken from the margin of 9 days old pure culture of each fungus, seeded at the center of Petri dishe and incubated at $28 \pm 2{ }^{\circ} \mathrm{C}$. Oils were previously mixed with DMSO (Dimethylsulfoxide) to obtain a final concentration of $10 \%(\mathrm{v} / \mathrm{v})$ and added into the medium to produce final concentrations of $0.5,1,2,3,4$ and $5 \mathrm{mg} / \mathrm{ml}$. Plate containing SDA with DMSO was negative control while griseofulvine served as positive control. Each treatment consisted of four Petri plates and the experiment repeated twice. After 14 days of incubation, the antifungal activity of each essential oil was evaluated by calculating the percentage of inhibition $(\% \mathrm{I})$ of mycelia growth using the following formula: \% I = ((Do De)/Do) x 100 where Do is the diameter of the mycelia growth in the negative control and De the diameter of the mycelia growth in each oil supplemented plates. Fungistatic or fungicide effect of oils was determined by transferring the discs from the plate where no growth occurred in to the new SDA medium.

\section{Antioxidant assay}

This was carried out by scavenging of the stable 2,2-diphenylpicrylhydrazyl (DPPH) radical according to the method describe by Brand-William [18]. Ten microlitres of various concentrations (1 to $5 \mathrm{mg} / \mathrm{ml}$ ) of each essential oil in methanol was added to $1990 \mu \mathrm{l}$ of a $10 \mathrm{mg} / \mathrm{ml}$ methanol solution of DPPH. After $60 \mathrm{~min}$ incubation period at room temperature, the absorbance was read at $517 \mathrm{~nm}$. Percentage inhibition of the DPPH free radical (I \%) was measured using the following equation: $(\%) \mathrm{I}=\left(\mathrm{A}_{\mathrm{DPPH}}-\mathrm{A}_{\text {sample }} / \mathrm{A}_{\mathrm{DPPH}}\right) \mathrm{x} 100$, where $\mathrm{A}_{\mathrm{DPPH}}$ is optical density of the positive control, $\mathrm{A}_{\text {sample }}$ is optical density of the essay (essential oil). Butyl Hydroxy Toluene (BHT) was used as a standard chemical reference antioxidant at the various concentrations ranging from 0.04 to $0.4 \mathrm{mg} / \mathrm{ml}$.

\section{Statistical analysis}

Data were analyzed using SPSS version 16.0. Results were expressed in term of means. Multiple comparisons of mean values were set up using one-way parametric ANOVA. The DUNCAN test was used to appreciate the differences between the means at $\mathrm{p}<0.05$. The relationship between the different parameters was done using Pearson correlation.

\section{RESULTS AND DISCUSION}

\section{Extraction and chemical composition of the essential oils}


Essential oils were obtained by hydrodistillation with yield of $0.025 \%$ and $1.45 \%$ respectively, from leaves and fruits (Table 1). Twenty one and twenty six compounds were identified representing $96.0 \%$ and $100 \%$ volatile oil from leaves and fruits respectively. The major component of the leaves oil was (E)-B- Ocimene $(91.5 \%)$ while (E)- $\beta$-Ocimene $(90.3 \%)$ is the major components of the fruit oil. However, some minor components were present only in the leaf oil $(\alpha$-Pinene, Limonene, (2E)-Octen-1-ol, Linalol, Nobornyl acetate, Octyl acetate, Neryl acetate and Germacreme B) and fruit oil ( $\alpha$ Terpinene, $\beta$-Phellandrene, $\Upsilon$-Terpinene, Cis-Linalool axide, $\alpha$-Pinene oxide, Cis-para-menth-2-enol, Allo-ocimene, Myrtenol, $\alpha$-Terpineol, Myrtenal, Pinocarvone, $\Upsilon$-Curcumene and Trans $\beta$-Guiaene). The essential oils of Z. leuprieuriifrom different countries including Cameroon have been already studied. The analysis reveals a great degree of variability and plasticity in Zanthoxylum essential oil yield and composition[19, 20]. From leaves oil of Costa Rica, [20]obtained 1.35\% yield, and a total of 12 components. The major components were citronellal (23.3\%), limonene (16.7\%), transpinocamphone (11.6\%), and $\beta$-pinene (10.8\%). Fogang[34] obtained $(E)$ - $\beta$-ocimene (29.4\%), myrcene (28.6\%), limonene $(13.6 \%)$ and $\alpha$-pinene $(8.1 \%)$ as the major compounds in leaves oil from Cameroon.[35]studied Z. leprieuriivolatile oils from leaves and fruits of Cameroon. Their results showed that the oil distilled from the leaves contained only hydrocarbons. Among them, $\alpha$-pinene $(40.4 \%)$, myrcene $(27.1 \%)$ and trans- $\beta$-ocimene $(22.4 \%)$ were the most important. The composition of the fruit oil is more diverse, with a fairly large proportion of oxygenated products $(46 \%)$ among which citronellol, geraniol and their acetates are the most abundant. Globally, these components were quantitatively and qualitatively different from those obtained in our study. In general, it is well demonstrated that, variation in yield and chemical composition could by explain by the extrinsic and intrinsic parameters such as the age of the plant, organ, soil, climate and ecological factors $[21,22]$.

Table 1: Chemical composition of leaves and fruits essential oils of Zanthoxylum leprieurii

\begin{tabular}{|c|c|c|c|c|}
\hline $\mathrm{N}^{\circ}$ & Compounds & $* \mathrm{KI}$ & Relative & \\
\hline & & & Leaves & Fruits \\
\hline 1 & $\alpha$-Thujiene & 925 & 0.3 & 0.2 \\
\hline 2 & $\alpha$-Pinene & 943 & 0.1 & - \\
\hline 3 & Camphene & 954 & 0.1 & 0.1 \\
\hline 4 & $\beta$-Pinene & 977 & 0.1 & 0.1 \\
\hline 5 & Octanol & 983 & 0.1 & 0.3 \\
\hline 6 & Myrcene & 990 & - & 2.3 \\
\hline 7 & $\alpha$-Phellandrene & 1000 & 0.8 & 0.1 \\
\hline 8 & $\alpha$ - Terpinene & 1004 & - & 0.1 \\
\hline 9 & p-Cymene & 1022 & 0.1 & 0.8 \\
\hline 10 & $\beta$-Phellandrene & 1029 & - & 0.1 \\
\hline 11 & Limonene & 1032 & 0.2 & - \\
\hline 12 & (E) - $\square$-Ocimene & 1039 & 91.5 & 90.3 \\
\hline 13 & (2E)-Octen 1-ol & 1059 & 0.4 & - \\
\hline 14 & $\Upsilon$-Terpinene & 1055 & - & 0.5 \\
\hline 15 & Terpinolene & 1087 & 0.2 & 0.1 \\
\hline 16 & Cis-Linalool oxide (furanoid) & 1084 & - & 0.1 \\
\hline 17 & Linalol & 1090 & 0.1 & - \\
\hline 18 & $\alpha$-pinene oxide & 1093 & - & 0.5 \\
\hline 19 & Pinocarveol & 1109 & 0.4 & 2.8 \\
\hline 20 & cis-p-Menth-2-en-1-ol & 1118 & - & 0.1 \\
\hline 21 & $\alpha$-Campholenal & 1124 & - & 0.3 \\
\hline 22 & Norbornyl acetate & 1127 & 0.2 & - \\
\hline 23 & Allo-ocimene & 1128 & - & 0.2 \\
\hline 24 & t-Pinocarveol & 1132 & 0.6 & 0.2 \\
\hline 25 & Acetate & 1186 & 0.1 & 0.1 \\
\hline 26 & Myrtenol & 1190 & - & 0.1 \\
\hline 27 & $\alpha$-Terpineol & 1192 & - & 0.1 \\
\hline 28 & Myrtenal & 1194 & - & 0.2 \\
\hline 29 & Octylacetate & 1196 & 0.1 & - \\
\hline 30 & Pinocarvone & 1343 & - & 0.1 \\
\hline 31 & Neryl acetate & 1345 & 0.2 & - \\
\hline 32 & $\gamma$-Curcumene & 1472 & - & 0.1 \\
\hline 33 & Germacrene B & 1475 & 0.2 & \\
\hline 34 & Trans- $\beta$-guaiene & 1512 & - & 0.1 \\
\hline 35 & $(2 \mathrm{E}, 6 \mathrm{E})-$ Farnesyl acetate & 1840 & 0.1 & - \\
\hline 36 & Farnesyl acetone & 1850 & 0.1 & - \\
\hline \multirow{2}{*}{\multicolumn{2}{|c|}{$\begin{array}{l}\text { Total } \\
\text { Yield }(\%)\end{array}$}} & & 96.0 & 100 \\
\hline & & & 0.025 & 1.45 \\
\hline
\end{tabular}

\section{*KI Kovats index was determined by Gas Chromatography on a $\mathrm{DB}_{5}$ column}

\section{Effects of essential oils on mycelia growth of E. floccosum and T. rubrum}

Essential oils from leaves and fruits of $Z$. leprieurii showed activity in inhibiting the growth of E. floccosum and T. rubrum (Table 2). In fact, results showed that, there are significant differences $(p<0.05)$ in the mycelia growth of each EOs supplemented samples compared with the negative control. Total inhibition of mycelia growth of $T$. rubrum occurred at 3.0 $\mathrm{mg} / \mathrm{ml}$ and $4.0 \mathrm{mg} / \mathrm{ml}$ by EOs from fruits and leaves respectively while E. floccosumwas completely inhibited at $4.0 \mathrm{mg} / \mathrm{ml}$ by the oils. Maximal inhibition by Gliseofulvin was observed at $5 \mathrm{mg} / \mathrm{ml}$ i.e $75.0 \%$ for T. rubrum and $65.35 \%$ for $E$. floccosum.

Many studies have also been reported on the antifungal activities of Zanthoxylum essential oil[23,24,25,26]. The antifungal properties of our samples could be due to the complexity of their chemical composition and structure of their different 
constituents. It could also be due to the presence of the main compound such as ocimene or to a possible synergistic effect of the minor or major compounds in the essential oil[27,28].The antifungal activities of compounds present in our tested essential oils may be explained to their lipophilic character and ability to disrupt the cellular membrane permeability and lead to the death of the cell [11].

Table 2 Mycelia growth inhibition of T. rubrum and E. floccosum by leaves and fruits essential oil of Z. leprieurii

\begin{tabular}{lllllll}
\hline Oils & \multicolumn{3}{c}{ T. rubrum } & \multicolumn{2}{c}{ E. floccosum } \\
\cline { 2 - 6 } Conc $(\mathrm{mg} / \mathrm{ml})$ & \multicolumn{1}{c}{ Leaves } & Fruits & Griseofulvine & Leaves & Fruits & Griseofulvine \\
\cline { 2 - 7 } 0.0 & \multicolumn{5}{c}{ Inhibition percentage $(\%)$} \\
0.5 & $0.0^{\mathrm{f}}$ & $0.0^{\mathrm{f}}$ & $0.0^{\mathrm{d}}$ & $0.0^{\mathrm{f}}$ & $0.0^{\mathrm{f}}$ & $0.0^{\mathrm{c}}$ \\
1.0 & $15.0^{\mathrm{e}}$ & $16.0^{\mathrm{d}}$ & $56.0^{\mathrm{c}}$ & $24.0^{\mathrm{d}}$ & $21.66^{\mathrm{d}}$ & $50.0^{\mathrm{b}}$ \\
2.0 & $30.33^{\mathrm{d}}$ & $43.33^{\mathrm{c}}$ & $58.0^{\mathrm{c}}$ & $37.0^{\mathrm{c}}$ & $41.0^{\mathrm{c}}$ & $52.0^{\mathrm{b}}$ \\
3.0 & $69.0^{\mathrm{c}}$ & $64.66^{\mathrm{b}}$ & $64.0^{\mathrm{b}}$ & $37.3^{\mathrm{c}}$ & $41.0^{\mathrm{c}}$ & $55.5^{\mathrm{b}}$ \\
4.0 & $88.0^{\mathrm{b}}$ & $100.0^{\mathrm{a}}$ & $67.33^{\mathrm{b}}$ & $58.66^{\mathrm{b}}$ & $56.33^{\mathrm{b}}$ & $58.5^{\mathrm{ab}}$ \\
5.0 & $100.0^{\mathrm{a}}$ & $100.0^{\mathrm{a}}$ & $70.0^{\mathrm{a}}$ & $100.0^{\mathrm{a}}$ & $100.0^{\mathrm{a}}$ & $61.5^{\mathrm{a}}$ \\
\hline
\end{tabular}

In the same column, values followed with the same letter are not significantly different $(\mathrm{p} \leq 0.05)$ according to Duncan multiple range test.

\section{Antioxidant activities of essential oils}

Oils from leaves and fruits of $Z$. leprieuriishowed effective free radical scavenging in DPPH assay (Figure 1). The antioxidant activities increase significantly with the concentration of each essential oil. The oils from fruits exhibited a remarkable antioxidant effects at low concentration with $\mathrm{SC}_{50}$ at $2 \mathrm{mg} / \mathrm{ml}$, while $\mathrm{SC}_{50}$ from leaves oils was $5 \mathrm{mg} / \mathrm{ml}$. Nevertheless, at all concentration tested, the chemical standard antioxidant BHT had a great effect compare to our oils sample and exhibited the most less $\mathrm{SC}_{50}(0.25 \mathrm{mg} / \mathrm{ml})$. It has been demonstrated that plant extract and volatile essential oil can exhibit significant antioxidant activities [29,30,31]. This property could be assigned to many compounds such as aromatic and oxygenated monoterpenes [32,33,34]which are presents in our essential oils. Similarly, [11] showed that, antioxidant and antimicrobial activities of essential oil could be related to the presence of a variety of volatile molecules such as terperne and terpenoid, phenol derived aromatic components and aromatic components. Free-radicals are generated continuously in the body due to metabolism and diseases [35]. In order to protect themselves against free radicals, organisms are endowed with endogenous (catalase, superoxide dismutase, glutathione peroxidase/reductase) and exogenous (C and E vitamins, carotene, uric acid) defense systems. These defense systems are not sufficient in critical situations such as oxidative stress, contamination, microbial infections, where the production of free radicals significantly increases [36].In our study, results showed that there are positive and significant correlations between the mycelia growth inhibition of $E$. floccosum and antioxidant activity of fruits $\left(r^{2}=0.524 ; p=0.025\right)$ and leaves Eos $\left(r^{2}=0.734 ; p=0.01\right)$. Positive correlation were also observed between T. rubrumgrowth inhibition and antioxidant properties $\left(r^{2}=0.959 ; p=0.000 ; r^{2}=0.974 ; p=\right.$ 0.000) respectively, from fruits and leaves Eos. [37]studied the oil from Zanthoxylumsp. and found that, it had antifungal and strong antioxidant activity. There is increasing evidence that indigenous antioxidants may be useful in preventing the deleterious consequences of oxidative stress and there is increasing interest in the protective biochemical functions of natural antioxidants contained in spices, herbs and medicinal plants.

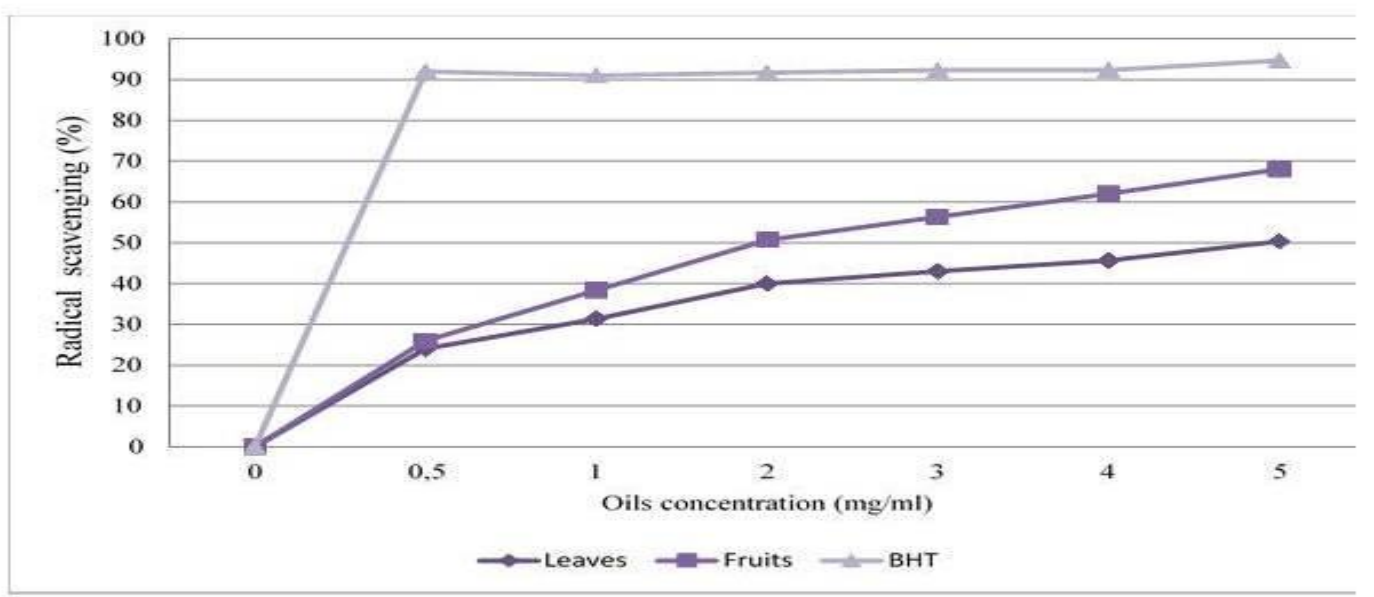

Figure 1: Antioxidant activities of leaves and fruits essential oils of Z. leprieurii

\section{CONCLUSION}

As our results is concerned, leaves and fruits of Z. leprieuriiessential oils significantly inhibit the mycelia growth of $E$. floccosumand T. rubrum. They also have antioxidant properties. These could be assigned to the synergistic effects of minor and major components in the oils. This finding demonstrated that, Z. leprieurii essential oils could be served as alternative to 
chemical fungicide to fight against dermatophytosis. Moreover, these oils are potential natural antioxidant. However, in vivo tests are needed.

\section{REFERENCES}

[1] Canizares, O. and Harman, R. Clinical tropical dermatology. 1992; $2^{\text {nd }}$ ed. Boston: Blackwell $\quad$ Scientific Publications $859 \mathrm{p}$

[2] Summerbell, R.C., Weitzman I. and Padhye A. Trichophyton,Microsporum,Epidermophytonandagents of superficial mycoses. 2007; Manual ofClinical Microbiology. Ch.124. 9th ed. ASM Press. Washington, DC. P1874-1897.

[3] Elewski, B.E. Onychomycosis: Pathogenesis, Diagnosis, and Management. 1998; Clinical. Microbiology. Review. 11(3): 415-429.

[4] Mau, J.L., Chao, G.R., and Wu, K.T. Antioxidant properties of methanolic extracts from several mushrooms. 2001; Journal of. Agriculture and Food Chemistry. 49(11):5461-5467.

[5] Pinto, E., Silva, L.V., Cavaleiro, C., and Salgueiro, L. Antifungal activity of the clove essential oil from Syzygiumaromaticum on Candida, Aspergillus and dermatophyte species. 2009; Journal of Medecine and Microbiology. 58:1454-1462.

[6] Kauffman, C.A. Fungal infections. 2006; American. Thorac. Society. (3): 35-40.

[7] Rapp, R. P. Changing strategies for the management of invasive fungal infections. 2004; Pharmacotherapy 24: 4S$28 \mathrm{~S}$.

[8] Sameza, M.L., Bedine, B.M.A.,Tchameni, N.S., Nguemnang, M.L.C., Jazet, D.P.M., Fekam, B.F., and Menut, C. Potential use of Eucalyptus globulusessential oil against Phytophthoracolocasiae the causal agent of taro leaf blight. 2014; European Journal of Plants Pathology. 140:243-250.

[9] Delazar, A., Yari, S.M., Chaparzadeh, N., Asnaashari, N., Nahar, L., Delazar, N. and Sarker, D.S.

Chemical composition, free-radical-scavenging and insecticidal properties, and general toxicity of volatile oils isolated from various parts of Echinophoraorientalis. 2015; Journal of Essential Oil Bearing Plants 18(6):12871297.

[10] Afshar H.E., Delazar, A.,Nazemiyeh, H., Asnaashari, S., Nahar, L., and Sarker, S. D. Chemical composition, free-radical-scavenging and insecticidal properties, and general toxicity of volatile oils of two Artemisia species growing wild in Iran.2015; Journal of Essential Oil Bearing Plants 18(6) 1406-1416.

[11] Bakkali, F., Averbeck, S., Averbeck, D. and Idaomar, M. Biological effects of essential oils: A review. 2008; Food Chemistry andToxicology. 46: 446-475.

[12] Wouatsa, N.A.V., Misra, L., Kumar, S., Prakash, O., Khan, F., Tchoumbougnang, F. and Venkatesh, $\quad$ R.K. Aromatase and glycosyltransferase inhibiting acridone alkaloids from fruits of Cameroonian Zanthoxylum species. 2013; Chemycal. Central Journal. 7:1-25. 576:180-188.

[13] Tatsadjieu, L.N., EssiaNgang, J.J., Ngassoum, M.B. and Etoa, F.X. Antibacterial and antifungal activity of Xylopiaaethiopica, Monodoramyristica, Zanthoxylumxanthoxyloides and Zanthoxylum

leprieurii from Cameroon. 2003; Fitoterapia 74: 469-472.

[14] Adams, R. P. Identification of essential oil components by gas chromatography mass spectrometry. 2007; Illinois: Allured Publishing Corporation. 495p.

[15] Rippon, J.W. Medical Mycology.The Pathogenic Fungi and the Pathogenic Actinomycetes. 1988; 3rd ed., WB Saunders, Philadelphia, 797 pp.

[16] Emmons, C.W., C.H. Binford, and Utz, J.P. 1970; Medical mycology, 2nd ed. Lea\&Febiger, Philadelphia.

[17] Lahlou, M. Methods to study the phytochemistry and bioactivity of essential oils. 2004; Phytotherapy Research, 18,435-448.

[18] Brand-William, W., Curvelier, M.E. and Berset, C.Use of a free radical method to evaluate antioxidant.1995;Lebensmittel-Wissenschaf und-Technologie 28(1):25-30

[19] Jazet, D.P.M., Tatsadjieu, N.L., Manedong, K.S., Ndongson, D.B., Amvam, Z.P.H. and Menut, C. Inhibitory effect of essential oils of some Cameroonian Zanthoxylum(Rutaceae) Against $\quad$ Fusariumsolani. 2009; European Journal of Scientific Research 34(1): 34-45.

[20] Miller, S.L., Haber, W.A. and Setzer, W.N. Chemical composition of the leaf essential oil of an species of Zanthoxylum from Monteverde, Costa Rica. American. Journal of Essential Oils

undescribed

and Natural Product. 2013; 1(2): 38-40.

[21] Vila, R., Iglesias, J., Cañigueral, S. and Cicció, J.F. Composition of the essential oil from leaves of Zanthoxylumprocerumfrom Costa Rica. 2002 Journal of Essential. Oil Research. 14:44-46.

[22] Oyedeji, A.O., Lawal, O.A., Adeniyi, B.A., Alaka, S.A., and Tetede, E. Essential oil composition of three Zanthoxylumspecies. Journal of Essential. Oil Research 2008; 20: 69-71.

[23] Silva, D.S.L., Figueiredo, P.M.S. and Yano, T. Chemotherapeutic potential of the volatile oils from ZanthoxylumrhoifoliumLam leaves. 2007; European Journal of Pharmacology. 576:180-188

[24] Jazet, D.P.M., Tchoumbougnang, F., Ndongson, B., Agwanande, W., Sandjon, B., Amvam, Z.P.H. and Menut, C. Chemical characterization, antiradical, antioxidant and anti-inflammatory potential of the essential oils of Canariumschweinfurthii and Aucoumeaklaineana (Burseraceae) growing in Cameroon. Agricuture and Biological Journal of North Americam. 2010; 1(4): 606-611.

[25] Ngoumfo, R. M., Jouda, J.B., Mouafo, F.T., Komguem, J., Mbazoa, C.D., Shiao, T.C., $\quad$ Choudhary, $\quad$ M.I., Laatsch, H., Legault, J., Pichette, A., and Roy, R. In vitro cytotoxic activity of isolated acridones alkaloids from Zanthoxylumleprieurii2010; Bioorg Med Chemistry 18: 3601-3605.

[26] Patiño, O.J.R., Prieto, J.A. and Cuca, L.E. Zanthoxylum Genus as Potential Source of Bioactive Compounds in Phytomedicine, 2011; Edited by IrajRasooli. JanezaTrdine 9, 51000 Rijeka, Croatia 185-218 
[27] Delaquis, P.J., Stanich, K., Girard, B. and Mazza, G. Antimicrobial activity of individual and mixed fraction of dill, cilantro, coriander and eucalyptus essential oil. 2002; InternationalJournalof . Food and Microbioogy. 74(1-2): 101-110.

[28] Vila, R., Santana, A. I., Pérez-Rosés, R., Valderrama, A., Castelli, V., Mendonca, S., et al.(2010). Composition and biological activity of the essential oil from leaves of Pliniacerrocampanensis, a new source of a bisabolol; 2010; Bioresource Technology153(1-2): 183-191.

[29] Tchinda, T.A., Fuendjiep, Sajjad A, Matchawe, C., Wafo, P., Khan, S., Tane, P. and Choudhary, M.I.Bioactive compounds from the fruits of Zanthoxylumleprieurii. 2009; Pharmacology online ; 1: 406-415.

[30] Xia, L., You, J., Li, G., Sun, Z., and Suo, Y. Compositional and Antioxidant Analysis of Zanthoxylumbungeanum seed oil obtained by Supercritical $\mathrm{CO}_{2}$ Fluid Extraction. 2011: Journal American Oil Chemestry $\quad$ Society. 88 (7): 1029-1036.

[31] Boone, G. L., Román, R. A., Aranda, R. S., Cirio, R.T., Galindo, V.R.R., Torres, W. N., González, R. and López, P.L.A. Antimicrobial and antioxidant activities and chemical characterization of essential oils of Thymus vulgaris, Rosmarinusofficinalis, and Origanummajoranafrom northeastern México. 2015; Pakistan Journal of Pharmacological Science . 28(1):363-369.

[32] Chatterjee,S., Gautam, S.Z.N., Adhikari, S., Variyar,S.P. and Sharma, A. Antioxidant activity of some phenolic constituents from green pepper (Piper nigrum L.) and fresh nutmeg mace $\quad$ (Myristicafragrans) 2007; Food Chemistry. 101(2), 515-523.

[33] Yamazaki, E., Inagaki, M., Kurita, O. and Inoue, T. Antioxidant activity of Japanese pepper (Zanthoxylumpiperitum DC.) fruit. 2007; Food Chemistry. 100: 171-177.

[34] Fogang, P.D.H., Tapondjou, A.L., Womeni, M.H., Quassinti, L., Bramucci, M., Vitali, A.L., $\quad$ Petrelli, $\quad$ D., Lupidi, G., Maggi, F. Papa, F., Vittoric, S. and Barbonid, L. Characterization and biological activity of essential oils from fruits of Zanthoxylumxanthoxyloides Lam. and Z. leprieuriiGuill. \&Perr: two culinary plants from Cameroon. 2009; Flavour and Fragrance Journal. 27: 171-179.

[35] Yeum, K.J., Aldini, G., and Chung, H.Y. The activities of antioxidant nutrients in human plasma depend on the localization of attracting radical species. 2003; The JournalNutriment. 133: 2688-2691.

[36] Mondon, P., Leclercq, L. and Lintner, K. Evaluation of free radical scavenger effects of Helianthusannuus extracts using new in vivotripping methods.1999; Cosmetics Aerosols and toiletries in Australia. 12: 87-98

[37] .Prakash, B., Singh, P., Mishra, P.K., and Dubey, N.K. Safety assessment of ZanthoxylumalatumRoxb essential oil, its antifungal, antiaflatoxin, antioxidant activity and efficacy as antimicrobial in preservation of Piper nigrum L.fruits.2012: International Journal Food Microbiology. 153(1-2): 183-191 